Katarina Marinčič

UDK 82.091"17"

Faculty of Arts, University of Ljubljana

DOI: 10.4312/vestnik.11.315-325

Slovenia

katarina.marincic@ff.uni-lj.si

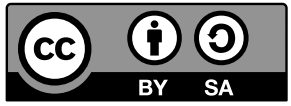

\title{
A WARDROBE SUITABLE FOR A VIRTUOUS PAUPER
}

The subject of this paper is not the influence of Pierre de Marivaux's La Vie de Marianne upon Samuel Richardson's Pamela. This question has been widely discussed since the 18 th century, more recently in the context of the history of literary translation. ${ }^{1}$

The furore over Pamela and Clarissa among French readers was in fact preceded by the success of Marivaux's novels in England. Before Richardson was fervently admired by Diderot (as well as admiringly, although not very faithfully translated by Prévost $^{2}$ ), Marivaux had received praise from both Henry Fielding and Laurence Sterne ${ }^{3}$.

Unlike Diderot, Prévost, Fielding and Sterne, who were all able to enjoy the originals, Richardson was dependent on translations ${ }^{4}$. Another proof of Marivaux's popularity in 18th century England: three different but related English translations of La Vie de Marianne appeared between 1736 and 1746 and were reprinted at least a dozen times by 1786 . In the case of Richardson and Marivaux, the abundance of possible sources presents a particular challenge for Quellenforschung. We may add to this the long and complicated genesis of La Vie de Marianne. Written in the years between 1728 and 1742, published in volumes between 1731 and 1742, the novel was intentionally (or rather whimsically) left unfinished. A sequel, also unfinished, was produced by Mme Riccoboni and published in 1745. An apocryphal sequel, this one containing a denouement, was sometimes wrongly attributed to Mme Riccoboni. (Richardson's Pamela was first published in 1740. The author himself, and later his daughters, revised and released fourteen editions of Pamela, the last of which was published in 1801.)

\footnotetext{
1 "The question of whether or not Richardson was influenced by Marivaux is a hardy perennial of Richardson criticism: it has been with us since the eighteenth century, and few modern biographers or critics fail to devote at least some attention to it." (Munro 1975: 752)

2 "Le traducteur français considère qu'il a non seulement toute liberté pour supprimer certains passages, mais également pour en écrire d'autres à son cru. Prévost dans la préface de sa traduction de Sir Charles Grandison justifie les coupes faites: 'J'ai donné une nouvelle face à son ouvrage par le retranchement des excursions languissantes, des peintures surchargées, des conversations inutiles et des refléxions déplacées." (Montadon 1999: 21)

3 "Both Fielding and Sterne read and admired him." (Baldwin 1912: 185)

4 Cf. Sard Hughes 1917: 108.
} 
The heroines of the two novels are both young, pretty and virtuous - whatever virtuous means. They are both first-person narrators, recounting their fortunes and misfortunes with a chattiness typical of their sex. However, in spite of these and some other obvious similarities ${ }^{5}$, La Vie de Marianne and Pamela are two profoundly dissimilar novels ${ }^{6}$. Not only because of the social gap between the two heroines and - perhaps more importantly - between the two novelists. Even leaving aside the stylistic refinements (often lost in translation), there remains one fundamental difference between the two books. Pamela is a tale with a happy ending and a clear moral message. Heroically resisting his advances, the young woman brings her seducer to the brink of despair - and finally receives an offer of marriage from him. La vie de Marianne is an unfinished tale and, as such, ambiguous by its very nature. We do not know - we can only assume by the tone of her narrative - that Marianne (i.e. the Countess *** telling us the story of her life in retrospect) has achieved a certain level of prosperity, contentment and wisdom. But has she really, and by what means? Or is she still, at the very moment of telling us her story, une admirable hypocrite, as the fictional editor of the book calls her in one of his comments?

\section{3}

\section{A GIFT OF CLOTHES}

One thing, however, is certain. At a crucial moment of their stories, confronted with the first attempt upon their virtue, both heroines react in accordance with their sense of propriety in clothing (as well as with an acute fashion sense).

The two seducers, Monsieur de Climal and Mr. B, try to lure their victims with clothes - which is not an altogether bad approach. Upon receiving the gift, the girls display a naive and joyful gratitude.

Being French, the virtuous orphan Marianne is ever so slightly frivolous even in the most dangerous of circumstances.

/.../ Marianne, ajouta-t-il en me prenant la main, qu'il serrait imperceptiblement, ne seriez-vous pas un peu plus familière avec un ami qui vous voudrait autant de bien que je vous en veux ? Voilà ce que je demande : vous lui diriez vos sentiments, vos goûts ; vous aimeriez à le voir. Pourquoi ne feriez-vous pas

\footnotetext{
5 "The facts are, that it was entirely possible for Richardson to have read a considerable part of Marianne in translation before he finished writing Pamela. Secondly, the plots of the two novels have at least a superficial resemblance. Thirdly, the two heroines have many characteristics in common. Finally, the methods of narrating their experiences are strikingly similar. /.../ In view of these facts, the burden of proof would seem to rest upon those who contend that Richardson owed nothing to Marivaux." (Baldwin 1912: 185)

6 By this we do not imply that Richardson was immune to Marivaux's influence. On the contrary, La Vie de Marianne prompted him to make a polemical variation.
} 
de même avec moi ? Oh ! j'y veux mettre ordre absolument, ou nous aurons querelle ensemble. À propos, j'oubliais à vous donner de l'argent. Et en disant cela, il me mit quelques louis d'or dans la main. Je les refusai d'abord, et lui dis qu'il me restait quelque argent de la défunte ; mais, malgré cela, il me força de les prendre. Je les pris donc avec honte, car cela m'humiliait, mais je n'avais point de fierté à écouter là-dessus avec un homme qui s'était chargé de moi, pauvre orpheline, et qui paraissait vouloir me tenir lieu de père.

Je fis une révérence assez sérieuse en recevant ce qu'il me donnait. Eh ! me dit-il, ma chère Marianne, laissons là les révérences, et montrez-moi que vous êtes contente. Combien m'allez-vous saluer de fois pour un habit que je vais vous acheter ? voyons. Je ne fis pas, ce me semble, une grande attention à l'habit qu'il me promettait ; mais il dit cela d'un air si bon et si badin, qu'il me gagna le cour, je vous l'avoue : mes répugnances me quittèrent, un vif sentiment de reconnaissance en prit la place, et je me jetai sur son bras que j'embrassai de fort bonne grâce, et presque en pleurant de sensibilité. (La Vie de Marianne: 70)

Pamela's letter home is serious, almost solemn.

Dear Father and Mother,

My Master has been very kind since my last; for he has given me a Suit of my old Lady's Cloaths, and half a Dozen of her Shifts, and Six fine Handkerchiefs, and Three of her Cambrick Aprons, and Four Holland ones. The Cloaths are fine Silks, and too rich and too good for me, to be sure. I wish it was no Affront to him to make Money of them, and send it to you: it would do me more good.

You will be full of Fears, I warrant now, of some Design upon me, till I tell you, that he was with Mrs. Jervis when he gave them me; and he gave her a Mort of good Things, at the same Time, and bid her wear them in Remembrance of her good Friend, my Lady, his Mother. And when he gave me these fine Things, he said, These, Pamela, are for you; have them made fit for you, when your Mourning is laid by, and wear 'em for your good Mistress's sake. Mrs. Jervis gives you a very good Word; and I would have you continue to behave as prudently as you have done hitherto, and every body will be your Friend.

I was so surpris'd at his goodness, that I could not tell what to say. I curcheed to him, and to Mrs. Jervis for her good Word; and said, I wished I might be deserving of his Favour, and her Kindness: and nothing should be wanting in me, to the best of my Knowledge.

O how amiable a Thing is doing good!-It is all I envy great Folks for.

I always thought my young Master a fine Gentleman, as every body says he is: But he gave these good Things to us both with such a Graciousness, as I thought he looked like an Angel. (Pamela: 18) 
In both novels, the heroine recognizes (or at least begins to suspect) her benefactor's real intentions when the gift of clothing turns into a gift of lingerie.

L'habit fut acheté : je l'avais choisi ; il était noble et modeste, et tel qu'il aurait pu convenir à une fille de condition qui n'aurait point eu de bien. Après cela M. de Climal parla de linge, et effectivement j'en avais besoin. Encore autre achat que nous allâmes faire ; madame Dutour aurait pu lui fournir ce linge, mais il avait ses raisons pour n'en point prendre chez elle : c'est qu'il le voulait trop beau. Madame Dutour aurait trouvé la charité outrée ;/.../. Oh ! pour le coup, ce fut ce beau linge qu'il voulut que je prisse, qui me mit au fait de ses sentiments ; je m'étonnai même que l'habit, qui était très propre, m'eût encore laissé quelque doute, car la charité n'est pas galante dans ses présents ; l'amitié même, si secourable, donne du bon et ne songe point au magnifique. Les vertus des hommes ne remplissent que bien précisément leur devoir ; elles seraient plus volontiers mesquines que prodigues dans ce qu'elles font de bien : il n'y a que les vices qui n'ont point de ménage. Je lui dis tout bas que je ne voulais point de linge si distingué, je lui parlai sur ce ton-là sérieusement ; il se moqua de moi, et me dit : Vous êtes une enfant, taisez-vous, allez vous regarder dans le miroir, et voyez si ce linge est trop beau pour votre visage. Et puis, sans vouloir m'écouter, il alla son train. (La Vie de Marianne: 73)

\section{Dear Father,}

Since my last, my master gave me more fine Things. He called me up to my old Lady's Closet, and, pulling out her Drawers, he gave me Two Suits of fine Flanders lac'd Headcloths, Three Pair of fine Silk Shoes, two hardly the worse, and just fit for me; for my old Lady had a very little Foot; and several Ribbamds ant Topknots of all Colours, and Four Pair of fine white cotton Stockens, and Three Pair of fine Silk ones; and Two Pair of rich Stays, and a Pair of rich Silver Buckles in one Pair of the Shoes. I was quite astonish'd, and unable to speak for a while; but yet I was inwardly asham'd to take the Stockens; for Mrs. Jervis was not there: If she had, it would have been nothing. I believe I receiv'd them very awkwardly; for he smil'd at my Awkwardness; and said, Don't blush, Pamela: Dost think I don't know pretty Maids wear Shoes and Stockens?

I was so confounded at these Words, you might have beat me down with a Feather. For, you must think, there was no Answer to be made to this: So, like a Fool, I was ready to cry; and went away curcheeing and blushing, I am sure, up to the Ears; for, tho' there was no Harm in what he said, yet I did not know how to take it. But I went and told all to Mrs. Jervis, who said, God put it into his Heart to be good to me; and I must double my Diligence. It look'd to her, 
she said, as if he would fit me in Dress for a Waiting-maid's place on his Sister Lady Davers's own person.

But still your kind fatherly Cautions came into my Head, and made all these Gifts nothing near to me what they would have been. But yet, I hope, there is no Reason; for what Good could it do to him to harm such a simple Maiden as me? Besides, to be sure no Lady would look upon him, if he should so disgrace himself. So I will make myself easy; and, indeed, I should never have been otherwise, if you had not put it into my Head; for my Good, I know very well. (Pamela: 19)

Two things at least are notable about this letter. Firstly, it is a fine example of Richardson's realism, his attentiveness to detail so eloquently praised by Diderot:

Les détails de Richardson déplaisent et doivent déplaire à un homme frivole et dissipé ; mais ce n'est pas pour cet homme-là qu'il écrivait ; c'est pour l'homme tranquille et solitaire, qui a connu la vanité du bruit et des amusements du monde, et qui aime à habiter l'ombre d'une retraite, et à s'attendrir utilement dans le silence. /.../ Ils sont communs, dites-vous ; c'est ce qu'on voit tous les jours ! Vous vous trompez; c'est ce qui se passe tous les jours sous vos yeux, et que vous ne voyez jamais. /.../ Sachez que c'est à cette multitude de petites choses que tient l'illusion : il y a bien de la difficulté à les imaginer; il y en a bien encore à les rendre. (Éloge de Richardson: 217)

Secondly, a sixteen-year-old servant girl seeks advice from her father. In one respect at least, the humble Mr. Andrews - le vieux père de Pamela ${ }^{7}$ - is an Enlightenment man par excellence, just like Richardson and Diderot (and, for that matter, Laclos): a father taking interest in his daughter(s).

\section{BUILDING A CAPSULE WARDROBE}

Marianne, an orphan of unknown parents, has no one to turn to for advice. In her behaviour towards M. de Climal, she is guided by her own somewhat Jesuitical common sense.

/.../ je n'avais plus de retraite, et M. de Climal m'en donnait une ; je manquais de hardes, et il m'en achetait; et c'étaient de belles hardes que j'avais déjà essayées dans mon imagination, et j'avais trouvé qu'elles m'allaient à merveille. Mais je

7 “Cependant on ne voit point arriver à la porte du lord le vieux père de Paméla, qui a marché toute la nuit ; on ne l'entend point s'adresser aux valets de la maison, sans éprouver les plus violentes secousses." (Éloge de Richardson: 226) 
n'avais garde de m'arrêter à cet article qui se mêlait dans mes considérations, car j'aurais rougi du plaisir qu'il me faisait, et j'étais bien aise apparemment que ce plaisir fît son effet sans qu'il y eût de ma faute : souplesse admirable pour être innocent d'une sottise qu'on a envie de faire. Après cela, me dis-je, M. de Climal ne m'a point encore parlé de son amour ; peut-être même n'osera-t-il m'en parler de longtemps, et ce n'est point à moi à deviner le motif de ses soins. On m'a menée à lui comme à un homme charitable et pieux, il me fait du bien : tant pis pour lui si ce n'est pas dans de bonnes vues; je ne suis point obligée de lire dans sa conscience, et je ne serai complice de rien, tant qu'il ne s'expliquera pas ; ainsi j'attendrai qu'il me parle sans équivoque.

Ce petit cas de conscience ainsi décidé, mes scrupules se dissipèrent; et le linge et l'habit me parurent de bonne prise. (La Vie de Marianne: 74-75)

Marianne has no intention of becoming M. de Climal's mistress. She finds him repugnant, and besides that, she knows that there are better things waiting for her. When the moment of crisis arrives, her first impulse is to return the gifts. Or perhaps not quite the first impulse: even in extreme rage, she is able to calculate the aesthetic effect of her sacrifice.

Non, lui dis-je, ou plutôt lui criai-je, il ne me restera rien, car je prétends vous rendre tout, et je commence par votre argent, que j'ai heureusement sur moi : le voici, ajoutai-je en le jetant sur une table avec une action vive et rapide qui exprimait bien les mouvements d'un jeune petit cœur, fier, vertueux et insulté ; il n'y a plus que l'habit et le linge dont je vais tout à l'heure faire un paquet que vous emporterez dans votre carrosse, monsieur ; et comme j'ai sur moi quelquesunes de ces hardes-là, dont j'ai autant d'horreur que de vous, je ne veux que le temps d'aller me déshabiller dans ma chambre, et je suis à vous dans l'instant ; attendez-moi, sinon je vous promets de jeter le tout par la fenêtre.

Et pendant que je lui tenais ce discours, vous remarquerez que je détachais mes épingles, et que je me décoiffais, parce que la cornette que je portais venait de lui, de façon qu'en un moment elle fut ôtée, que je restai nu-tête avec ces beaux cheveux dont je vous ai parlé, et qui me descendaient jusqu'à la ceinture. (La vie de Marianne: 137)

Later on, in a rather predictable way, Marianne arrives at the conclusion that the best thing she can do is to keep the clothes.

Je ne songeais donc plus qu'à ma robe, qu'il fallait empaqueter aussi ; je dis celle que m'avait donnée M. de Climal ; et comme je l'avais sur moi, et qu'apparemment je reculais à l'ôter : N'y a-t-il plus rien à mettre ? disais-je ; est-ce 
là tout? Non, il y a encore l'argent; et cet argent, je le tirai sans aucune peine : je n'étais point avare, je n'étais que vaine : et voilà pourquoi le courage ne me manquait que sur la robe. /.../

Ce qui est certain, c'est que je décrochai l'ancienne, et qu'en soupirant encore, je me laissai tristement aller sur un siège, pour y dire ; Que je suis malheureuse ! Eh! mon Dieu ! pourquoi m'avez-vous ôté mon père et ma mère ?

Peut-être n'était-ce pas là ce que je voulais dire, et ne parlais-je de mes parents que pour rendre le sujet de mon affliction plus honnête ; car quelquefois on est glorieux avec soi-même, on fait des lâchetés qu'on ne veut pas savoir, et qu'on se déguise sous d'autres noms ; ainsi peut-être ne pleurais-je qu'à cause de mes hardes. Quoi qu'il en soit, après ce court monologue qui, malgré que j'en eusse, aurait fini par me déshabiller, j'allai par hasard jeter les yeux sur ma cornette qui était à côté de moi.

Bon, dis-je alors, je croyais avoir tout mis dans le paquet, et la voilà encore ; je ne songe pas seulement à en tirer une de ma cassette pour me recoiffer, et je suis nu-tête : quelle peine que tout cela ! Et corr, passant insensiblement d'une idée à une autre, mon religieux me revint dans l'esprit. Hélas ! le pauvre homme, me dis-je, il sera bien étonné quand il saura tout ceci.

Et tout de suite je pensai que je devais l'aller voir ; qu'il n'y avait point de temps à perdre ; que c'était le plus pressé à cause de ma situation ; /...

Oui ; mais quelle cornette mettrai-je ? Quelle cornette ? eh ! celle que j'avais ôtée, et qui était à côté de moi. C'était bien la peine d'aller fouiller dans ma cassette pour en tirer une autre, puisque j'avais celle-ci toute prête.

Et d'ailleurs, comme elle valait beaucoup mieux que la mienne, il était même à propos que je m'en servisse, afin de la montrer à ce religieux, qui jugerait, en la voyant, que celui qui me l'avait donnée y avait entendu finesse, et que ce ne pouvait pas être par charité qu'on en achetât de si belles : car j'avais dessein de conter mon aventure à ce bon moine, qui m'avait paru un vrai homme de bien : or, cette cornette serait une preuve sensible de ce que je lui dirais.

Et la robe que j'avais sur moi, eh vraiment ! il ne fallait pas l'ôter non plus : il est nécessaire qu'il la voie, elle sera une preuve encore plus forte.

Je la gardai donc et sans scrupule ; j'y étais autorisée par la raison même : l'art imperceptible de mes petits raisonnements m'avait conduite jusque-là, et je repris courage jusqu'à nouvel ordre. (La vie de Marianne: 145)

In the middle of these reflections, Marianne is offered some sound advice from her landlady:

/.../ je vous conseille une chose ; c'est de vous défaire de cette robe que M. de Climal vous a donnée. Vous ne pourriez plus honnêtement la porter à cette 
heure que vous allez être pauvre et sans ressource ; elle serait trop belle pour vous, aussi bien que ce linge si fin, qui ne servirait qu'à faire demander où vous l'avez pris. Croyez-moi, quand on est gentille et à votre âge, pauvreté et bravoure n'ont pas bon air ensemble; on ne sait qu'en dire. (Ibid.,141)

Due to her (presumably) aristocratic origin, Marianne is not susceptible to these plebeian warnings. Pamela, on the other hand, understands certain things without being told about them. Shy and naive as she is, she knows exactly how much clothes cost. More importantly, she knows what they mean.

I thought with myself some Days ago, Here I shall go home to my poor Father and Mother, and have nothing on my Back, that will be fit for my Condition; for how should your poor Daughter look with a Silk Night-gown, Silken Petticoats, Cambrick Head-cloaths, fine Holland Linen, lac'd Shoes, that were my Lady's, and fine Stockens! And how in a little while must these have look'd, like old Cast-offs, indeed, and I look'd so for wearing them! And People would have said, (for poor Folks are envious, as well as rich) See there Goody Andrews's Daughter, turned home from her fine Place! What a tawdry Figure she makes! And how well that Garb becomes her poor Parents' Circumstances! - And how would they look upon me, thought I to myself, when they should come to be in Tatters, and worn out? And how should I look, even if I could get homespun Cloths, to dwindle into them one by one, as I could get them?-May be, an old Silk Gown, and a Linsey-woolsey Petticoat, and so on. (Pamela: 44-45)

In a seemingly paradoxical way, Pamela, who had been given many fine things, finds herself in need of a new set of clothes.

So, thinks I, I had better get myself at once 'quipt in the Dress that would become my Condition; /.../

So, as I was saying, unknown to any body, I bought of Farmer Nichols's Wife and Daughters a good sad-colour'd Stuff, of their own Spinning, enough to make me a Gown and two Petticoats; and I made Robings and Facings of a pretty Bit of printed Calicoe, I had by me.

I had a pretty good Camlet quilted Coat, that I thought might do tolerably well; and I bought two Flannel Under-coats, not so good as my Swan-skin and fine Linen ones, but what will keep me warm, if any Neighbour should get me to go out to help 'em to milk, now-and-then, as sometimes I us'd to do formerly; for I am resolv'd to do all your good Neighbours what Kindness I can; and hope to make myself as much belov'd about you, as I am here. 
I got some pretty good Scots Cloth, and made me at Mornings and Nights, when nobody saw me, two Shifts, and I have enough left for two Shirts, and two Shifts, for you my dear Father and Mother. When I come home, I'll make 'em for you, and desire your Acceptance as my first Present.

Then I bought of a Pedlar, two pretty enough round-ear'd Caps, a little Straw Hat, and a Pair of knit Mittens, turned up with white Calicoe; and two Pair of ordinary blue Worsted Hose, that make a smartish Appearance, with white Clocks, I'll assure you; and two Yards of black Ribbon for my Shift Sleeves, and to serve as a Necklace; and when I had 'em all come home, I went and looked upon them once in two Hours, for two Days together: For, you must know, tho' I lay with Mrs. Jervis, I kept my own little Apartment still for my Cloaths; and nobody went thither but myself. You'll say I was no bad Housewife to have saved so much Money; but my dear good Lady was always giving me something. (Ibid., 45)

To say it once again with Diderot: "Ma foi, cela est vrai: on n'invente pas ces choses-là." (Les Deux Amis de Bourbonne: 277) Somehow, Pamela's inventory - or rather the fact that she is making one - still sounds true after almost three hundred years.

Inutile à dire, towards the end of the novel, we find her once again "dressing for duty" ${ }^{8 "}$, building yet another version of what today's fashion journalists call "a capsule wardrobe". This final version is, of course, suitable for a lady.

I Had a good deal of Employment in chusing Patterns for my new Cloaths. He thought nothing too good; but I thought every thing I saw was; and he was so kind to pick out Six of the richest, for me to choose three Suits out of, saying, we would furnish ourselves with more in Town, when we went thither. One was a white flower'd with Gold most richly; and he was pleased to say, that, as I was a Bride, I should make my Appearance in that the following Sunday. And so we shall have in two or three Days, from several Places, nothing but Mantua-makers and Tailors at Work. Bless me! what a chargeable and what a worthless Hussy I am, to the dear Gentleman!-But his Fortune and Station require a great deal of it; and his Value for me will not let him do less, than if he had marry'd a Fortune equal to his own: and then, as he says, it would be a Reflection upon him if he did.-And so I doubt it will be as it is: For either way the World will have something to say. He made me also chuse some very fine Laces, and Linen; and has sent a Message on purpose, with his Orders, to hasten all down; what can be done in Town, as the Millinery Matters, etc. to be completed there, and sent by particular Messengers, as done. All to be here, and finished by Saturday afternoon, without fail. (Pamela: 470)

8 Cf. Oliver 2008: 153. 


\section{BIBLIOGRAPHY}

MARIVAUX, Pierre de (1987) La Vie de Marianne. Paris: Gallimard.

RICHARDSON, Samuel (2001) Pamela. Oxford: OUP.

DIDEROT, Denis (1875) Eloge de Richardson; Les Deux Amis de Bourbonne (Euvres complètes V). Paris: Hachette.

BALDWIN, Edward Chauncey (1912) Marivaux's Place in the Development of Character Portrayal. PMLA, Vol. 27, No. 2, 168-187.

MONTADON, Alain (1999) Le roman au XVIIIe siècle en Europe. Paris: PUF.

MUNRO, James S. (1975) Richardson, Marivaux and the French Romance Tradition. The Modern Language Review 70, 752-759.

OLIVER, Kathleen M. (2008) Samuel Richardson, Dress, and Discourse. New York: Palgrave Macmillan.

SARD HUGHES, Helen (1917) Translations of the Vie de Marianne and Their Relation to Contemporary English Fiction. Modern Philology, Vol. 15, No. 8, 491-512.

\section{POVZETEK}

\section{Garderoba za krepostno, a revno dekle}

Tema pričujočega članka ni vpliv romana Marijanino življenje Pierra de Marivauxa na Pamelo Samuela Richardsona (vprašanje, s katerim se literarna zgodovina ukvarja že vse od 18. stoletja). Kljub nekaterim očitnim podobnostim sta Marijanino življenje in Pamela zelo različni knjigi. Pamela je povest s srečnim koncem in jasnim moralnim sporočilom. Marijanino življenje je nedokončana, torej že po naravi stvari dvoumna pripoved. Vendar pa se junakinji obeh knjig v ključnem trenutku, ko je ogrožena njuna krepost, odzoveta na enak način: vodi ju čut za spodobnost v oblačenju (ki je obenem tudi izostren občutek za modo). V obeh romanih si zapeljivec skuša pridobiti zaupanje potencialne žrtve tako, da jo obdaruje z lepimi oblačili. Junakinji obeh romanov darila sprejemata z naivnim, skoraj otroškim veseljem in hvaležnostjo. Nelagodje obe začutita šele v trenutku, ko se med podarjenimi stvarmi znajde razkošno spodnje perilo. Francozinja se po premisleku odloči, da bo podarjeno kljub vsemu obdržala. Pamela ni le manj popustljiva do sebe, ampak se izkaže tudi za mnogo modernejšo mlado žensko. V trenutku, ko sklene vrniti podarjene stvari, že začne intenzivno razmišljati o novi garderobi.

Ključne besede: Pierre de Marivaux, Samuel Richardson, Marijanino življenje, Pamela, spodobnost v oblačenju, moda 


\begin{abstract}
The subject of this paper is not the influence of Pierre de Marivaux's La Vie de Marianne upon Samuel Richardson's Pamela (a question that has been widely discussed since the 18 th century). In spite of some obvious similarities, La Vie de Marianne and Pamela are two profoundly dissimilar novels. Pamela is a tale with a happy ending and a clear moral message. La vie de Marianne is an unfinished tale and, as such, morally ambiguous by its very nature. However, at crucial moments of their stories, confronted with the first attempts upon their virtue, both heroines react in accordance with their sense of propriety in clothing as well as with an acute fashion sense. In both novels, the seducer tries to lure his victim with clothes. Upon receiving the gift, both girls display a naive and joyful gratitude. Their dilemma begins when the gift of clothing turns out to be a gift of lingerie. The self-indulgent French heroine, after a short reflection, decides to keep the clothes. Pamela turns out to be a much more modern young woman. She returns the gift and - in a seemingly paradoxical way - puts herself in need of a new set of clothes.
\end{abstract}

Keywords: Pierre de Marivaux, Samuel Richardson, La Vie de Marianne, Pamela, propriety in clothing, fashion 